\title{
MEMANFAATKAN ALGORITMA K-MEANS DALAM MENENTUKAN PEGAWAI YANG LAYAK MENGIKUTI ASESSMENT CENTER UNTUK CLUSTERING PROGRAM SDP
}

\author{
Iin Parlina ${ }^{1}$, Agus Perdana Windarto ${ }^{2}$, Anjar Wanto ${ }^{3}$, M.Ridwan Lubis ${ }^{4}$ \\ ${ }^{14}$ Dosen Amik Tunas Bangsa Pematangsiantar, ${ }^{23}$ Dosen STIKOM Tunas Bangsa \\ Jl.Jendral Sudirman Blok A No.1, 2, 3 Pematangsiantar \\ iin@amiktunasbangsa.ac.id ${ }^{l}$,agus@stikomtunasbangsa.ac.id ${ }^{2}$,anjar@stikomtunasbangsa.ac.id ${ }^{3}$, \\ Ridwan@amiktunasbangsa.ac.id ${ }^{4}$
}

\begin{abstract}
Abstrak - Data mining merupakan teknik pengolahan data dalam jumlah besar untuk pengelompokan. Teknik Data mining mempunyai beberapa metode dalam mengelompokkan salah satu teknik yang dipakai penulis saat ini adalah K-Means. Dalam hal ini penulis mengelompokan data daftar program SDP tahun 2017 untuk mengetahui manakah pegawai yang layak lolos dalam program SDP sehingga dapat melakukan Registrasi Asessment Center. Pengelompokan tersebut berdasarkan kriteria - kriteria data Program SDP. Pada penelitian ini, penulis menerapkan algoritma K-Means Clustering untuk pengelompokan data Program SDP di PT.Bank Syariah. Dalam hal ini, pada umumnya untuk memamasuki program SDP tersebut disesuaikan dengan ketentuan dan parameter Program SDP saja, namun dalam penelitian ini pengelompokan disesuaikan dengan kriteria - kriteria Program SDP seperti kedisiplinan pegawai, Target Kerja Pegawai, Kepatuhan Program SDP. Penulis menggunakan beberapa kriteria tersebut agar pengelompokan yang dihasilkan menjadi lebih optimal. Tujuan dari pengelompokan ini adalah terbentuknya kelompok SDP pada Program SDP yang menggunakan algoritma K-Means clustering. Hasil dari pengelompokan tersebut diperoleh tiga kelompok yaitu kelompok Lolos, Hampir Lolos dan Tidak Lolos. Terdapat pusat cluster dengan Cluster-1= 8;66;13, Cluster-2=10;71;14 dan Cluster-3=7;60;12. Pusat cluster tersebut didapat dari beberapa iterasi sehingga mengahasilakan pusat cluster yang optimal.
\end{abstract}

Kata kunci - K-Means, Data Mining, SDP

\section{PENDAHULUAN}

Clustering merupakan salah satu metode data mining yang bersifat tanpa arahan (unsupervised) dan suatu metode untuk mencari dan mengelompokan data yang memiliki kemiripan karakteristik antara satu data dengan data lain[9]. Menurut kategori kekompakan, pengelompokan terbagi menjadi dua, yaitu komplet dan parsial. Jika semua data dapat bergabung menjadi satu, dapat dikatakan semua data kompak menjadi satu kelompok[2]. Pada clustering ini terdapat beberapa algoritma pengelompokan untuk mengelompokan data secara mudah[1]. Salah satunya adalah algoritma $K$-Means yang merupakan metode analisis kelompok yang mengarah pada partisian $N$ objek pengamatan ke dalam $K$ kelompok, di mana setiap objek pengamatan sebuah kelompok data dengan mean (rata-rata) terdekat[2]. Pengelompokan pada umumnya diterapkan untuk mengelompokan dokumen atau benda yang tidak tersusun dengan rapi dan tidak sesuai sususannya pada tempatnya[7]. Namun fungsi dari pengelompokan tidak hanya sekedar mengelompokan dokumen atau benda[4]. Pengelompokan (clustering) dapat diterapkan dalam hal penentuan program SDP agar program SDP tersebut sesuai dengan kualifikasi dan memenuhi syarat untuk lanjut asessment center pada program SDP[1]. Banyak Perusahaan seperti Perusahaan dalam bidang Perbankan selama ini untuk promosi-promosi jabatan hanya menggunakan nilai fisik sebagai tolak ukur untuk memilih yang mengikuti program asessment center lanjutan, sehingga pada akhirnya Pelaksanaan Program SDP ini menjadi salah mengambil keputusan sehingga data yang terdaftar di program SDP tidak memenuhi syarat administratif. Dalam hal ini, untuk pengelompokan data yang masuk ke daftar pegawai dalam program SDP lanjutan adalah pegawai yang memenuhi kualifikasi sesuai persyaratan administrasi. Data yang dapat menjadi tolak ukur untuk pengelompokan program SDP yaitu Prestasi pegawai (Target Kerja 75\%), loyalitas pegawai (Kepatuhan $15 \%$ ) dan Kedisiplinan $10 \%$. Dengan demikian mengelompokan program SDP yang dilakukan akan lebih efektif bagi Program SDP itu sendiri. Algoritma $K$-Means dalam hal ini akan mengelompokan data tersebut sesuai kriteria - kriteria yang dipilih dari Program SDP.

\section{TINJAUAN PUSTAKA}

\section{A. Data Mining}

Istilah data mining mulai dikenal sejak tahun 1990, ketika pekerjaan pemanfaatan data menjadi 
sesuatu yang penting dalam berbagai bidang, mulai dari bidang akademik, bisnis hingga edisi[6]. Munculnya data mining didasarkan pada jumlah data yang tersimpan dalam basis data semakin besar[8]. Dalam berbagai literatur, teori-teori pada data mining sudah ada sejak lama seperti antara lain K-Means Clustering dan text mining. Data mining disebut juga dengan knowledge discovery in database (KDD) ataupun pattern recognition[8]. Istilah KDD atau disebut penemuan pengetahuan data karena tujuan utama data mining adalah untuk memanfaatkan data dalam basis data dengan mengolahnya sehingga menghasilkan informasi baru yang berguna[8]. Sedangkan istilah pattern recognition atau disebut pengenalan pola mempunyai tujuan pengetahuan yang akan digali dari dalam bongkahan data yang sedang dihadapi

\section{B. Dasar Cluster}

Analisis kelompok (cluster analysis) adalah mengelompokkan data (objek) yang didasarkan hanya pada informasi yang ditemukan dalam data yang menggambarkan objek tersebut dan hubungan diantaranya[1]. Analisis Cluster sebagai metodologi untuk klasifikasi data secara otomatis menjadi beberapa kelompok dengan menggunakan ukuran asosiasi, sehingga data yang sama berada dalam satu kelompok yang sama dan data yang berbeda berada dalam kelompok data yang tidak sama[9].

Masukan (input) untuk sistem analisis cluster adalah seperangkat data dan kesamaan ukuran (atau perbedaan) antara dua data. Sedangkan keluaran (output) dari analisis cluster adalah sejumlah kelompok yang membentuk sebuah partisi atau struktur partisi dari kumpulan data[10]. Salah satu hasil tambahan dari analisis cluster adalah deskripsi umum dari setiap cluster dan hal itu sangat penting untuk analisis lebih dalam dari karakteristik data set tersebut[9]. Ada saatnya di mana set data yang akan diproses dalam data mining belum diketahui label kelasnya. Pengelompokan data dilakukan dengan menggunakan algoritma yang sudah ditentukan dan selanjutnya data akan diproses oleh algoritma untuk dikelompokkan menurut karakteristik alaminya[6].

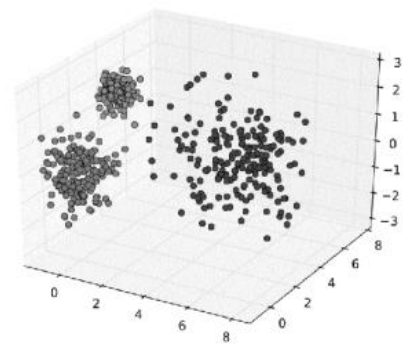

Gbr. 1 Pengelompokan dengan clustering

\section{Algoritma K-Means}

Algoritma K-Means merupakan algoritma pengelompokan iteratif yang melakukan partisi set data ke dalam sejumlah $K$ cluster yang sudah ditetapkan di awal[3]. Algoritam K-Means sederhana untuk diimplementasikan dan dijalankan, relatif cepat, mudah beradaptasi, umum Penggunaannya dalam praktek[2]. K-Means dapat diterapkan pada data yang direpresentasikan dalam r-dimensi ruang tempat[4]. Kmeans mengelompokan set data rdimensi, $\mathrm{X}=\{x i \mid i=1, \ldots, \mathrm{N}\}[5]$.

Algoritma $K$-Means pengelompokan semua titik data dalam $X$ sehingga setiap titik $x i$ hanya jatuh dalam satu $K$ partisi[5]. Tujuan pengelompokan ini adalah untuk meminimalkan fungsi objek yang diset dalam proses pengelompokan, yang pada umumnya berusaha meminimalkan variasi di dalam suatu kelompok dan memaksimalkan variasi antar kelompok[3].

Parameter yang hrsus dimasukkan ketika menggunakan algoritma $K$-Means adalah nilai $K[5]$. Nilai $K$ yang digunkan pada umumnya didasarkan pada informasi yang diketahui sebelumnya mengenai sebenarnya berapa banyak cluster yang muncul dalam $X$, berapa banyak yang digunakan untuk penerapnnya, atau jenis cluster dicari dengan melakukan percobaan dengan beberapa nilai $K$. Set representatif cluster dinyatakan $\mathrm{C}=\{c j \mid j=1, \ldots, \mathrm{K}$. sejumlah $K$ representatif cluster tersebut sebagai cluster centroid (titik pusat cluster)[10]. Untuk set data dalam $X$ dikelompokan berdasarkan konsep kedekatanatau kemiripan, namun kuantitas yang digunkan untuk mengukurnya adalah ketidak miripan[2]. Metrik yang umum digunakan untuk ketidak miripan tersebut adalah Euclidean[1]. Secara umum algoritma $K$-Means memiliki langkah-langkah dalam pengelompokan, diantaranya:

1. Inisilisasi: menentukan nilai $K$ centroid yang diinginkan dan metrik ketidakmiripan (jarak) yang diinginkan.

2. Memilih $K$ data dari set $X$ sebagai centroid. Untuk menentukan centroid dapat menggunakan persamaan (1).

$\frac{\text { Jumlah Data }}{\text { Jumlah Class }+1}$

3. Mengalokasikan semua data ke centroid terdekat dengan matrik jarak yang telah ditetapkan

4. Menghitung kembali centroid $C$ berdasarkan data yang mengikuti cluster masing-masing.

5. Mengulangi langkah 3 dan 4 hingga kondisi konvergen tercapai.

Berikut ini adalah rumus untuk menentukan jumlah cluster:

$$
\mathrm{K}=\sqrt{\frac{N}{2}}
$$


Keterangan:

$\mathrm{K}=$ klaster

$\mathrm{N}=$ jumlah data

Menghitung jarak pada ruang jarak Euclidean menggunakan formula:

Page | 89

$$
\begin{aligned}
& \mathrm{D}\left(x_{2}, x_{1}\right)=\left\|x_{2}-x_{1}\right\|_{2}= \\
& \sqrt{\sum_{j=1}^{p}\left|x_{2 j}-x_{1 j}\right|^{2}}
\end{aligned}
$$

Keterangan:

$D=$ euclidean distance

$x=$ banyaknya objek

$\Sigma \mathrm{p}=$ jumlah data record

\section{HASIL DAN PEMBAHASAN}

Penelitian ini bertujuan untuk mengelompokan data Program SDP baru sekolah menengah program SDP dengan menggunakan algoritma $K$-Means. Agar tercapai tujuan tersebut, penulis akan melakukan pengujian dengan menggunakan data pada salah satu Perusahaan Perbankan di Pematangsiantar yaitu PT.Bank Syariah Mandiri area-2 tahun 2017. Adapun pengelompokan tersebut menggunakan langkah - langkah sebagai berikut:

\section{A. Sumber Data}

Dalam penelitian ini, sumber data diambil dari PT. Bank Syariah Mandiri Pematangsiantar dimana data tersebut merupakan data pegawai yang masuk ke daftar Program SDP baru tahun 2017.

TABEL 1

\begin{tabular}{|c|c|c|c|c|c|c|}
\hline 10 & $\mathbb{R} \mathbb{P}$ & MaNA & HBATAISHTLII & 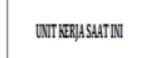 & 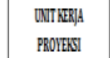 & AREA \\
\hline 1 & 108073387 & RenRhina & 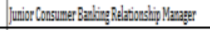 & KPPBanconter & Arebatam & Are Batan \\
\hline 2 & & 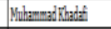 & 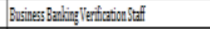 & 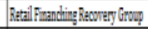 & MPPatam & Ara Batan \\
\hline 3 & 11007752007 & Musthiditin & 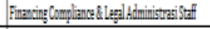 & 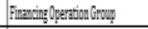 & Arabatm & Ara Bata \\
\hline 4 & 096673907 & Primistigan & 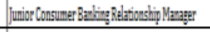 & KCPBataning & AreBtatm & Are Batan \\
\hline 5 & 111679651 & Mhanhly & 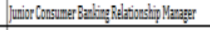 & MPP hambax & Arsabatm & Ara Bata \\
\hline 6 & 1118796455 & Asraflets & 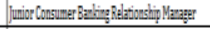 & KCPBtanBegatong & Arabatm & Ara Bata \\
\hline 7 & 128712213 & Anthesptian & 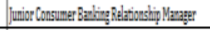 & KClags & RClangs & 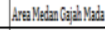 \\
\hline 8 & 128412364 & 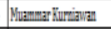 & 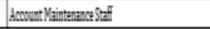 & Ratalfandinghovery Grop & Retalfinaring Regon & Aratgen \\
\hline 9 & 116570145 & Atyledi & 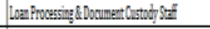 & 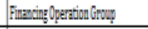 & Finneypoperation & Arebitam \\
\hline 10 & 106655118 & Adirgalaradi & 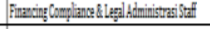 & Famecingor & Finneingoperdion & Arabiam \\
\hline 11 & $12089112 \%$ & Assiatlia & Costoner haris & KOPMensibbumi & IFPhadalare: & Araykinathad lan \\
\hline 12 & 128011825 & Shatrano & 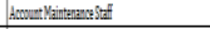 & Retal Fandingleovery Goup & Retalfimaring Ragon & Arelykinthadling \\
\hline 13 & 106653947 & Demarnhlanourgy: & 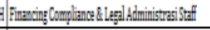 & 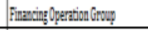 & Francingopation & Areplanbin \\
\hline 14 & 100566265 & Any0torngegs & 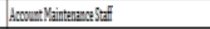 & 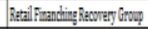 & 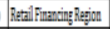 & 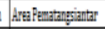 \\
\hline 15 & 108077016 & Alyjurilatis & 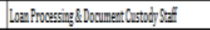 & 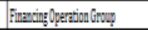 & Finnengoperation & Artefemangyintar \\
\hline 16 & 10056654 & 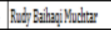 & 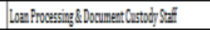 & 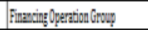 & Fmenchoperabon & Arathen \\
\hline 17 & 118579634 & Sardian & 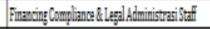 & Fineringoperition Group & Fimncingperation & Arakke \\
\hline 18 & 100566834 & with & AworetKintanssidf & 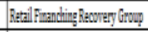 & Ratal Finaingligign & Aralykanciably:dia \\
\hline 19 & 118778661 & Detilunia & 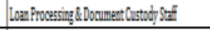 & 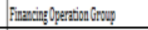 & 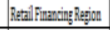 & Areplanbin \\
\hline 20 & 11867919 & Andigytu & 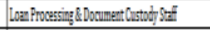 & 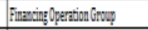 & Fanneypopation & Araphan Bn \\
\hline 21 & 1187798913 & Amilintiana & 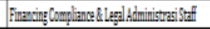 & 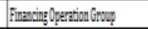 & Franengoperibon & Areplanban \\
\hline 2. & 128801064 & Spyadibaman & 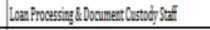 & 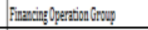 & Fancingopation & Arefearangintar \\
\hline 23 & 111859191 & Tismullarden & 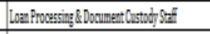 & Finasing 0 & Finangyoperation & AraPenatanginter \\
\hline 24 & 106575319 & Dibinan & Finering & 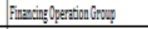 & Finnengoperation & Regon//Smaten 1 \\
\hline 5 & 008073284 & ssuth Rima & 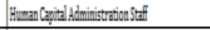 & Ragni//umstan 1 & Regon|/Bumsten1 & Regen//Bustan1 \\
\hline 26 & 108775315 & aditiblisplugng & 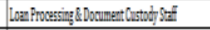 & 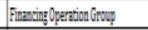 & Fanningoperaion & Regen//Smaten1 \\
\hline 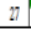 & 09657421 & Minldibugato & 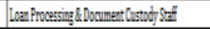 & 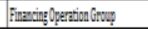 & Finnengopation & Regon:/Sematen 1 \\
\hline
\end{tabular}

DATA DAFTAR PROGRAM SDP TAHUN 2017

Gbr.2. Data Daftar Program SDP

\section{B. Pengolahan Data}

Sebelum data Program SDP dikelompokan ke dalam Seleksi SDP yang sesuai kriteria. Data mentah tersebut akan di transformasi dengan cara menginisialisasi data ke dalam bentuk angka yang dapat diolah dalam pengelompokan.

TABEL 2

RANGE PENGELOMPOKAN PROGRAM SDP

\begin{tabular}{|c|c|c|c|}
\hline Cluster & $\sum$ Min & $\sum$ Max & Cluster \\
\hline 1 & 6 & 18 & Kedisiplinan \\
\hline 2 & 10 & 13 & Kinerja \\
\hline 3 & 27 & 0 & Kepatuhan \\
\hline
\end{tabular}

Berdasarkan range yang telah ditentukan pada pengelompokan jurusan, maka dapat Disimpulkan bahwa pengelompokan data Program SDP ke dalam Asessment Center tanpa menggunakan metode. Pada data tersebut, tidak semua kriteria yang dapat menjadi patokan. Dalam hal ini, kriteria yang diinisialisasikan adalah Kedisiplinan diubah menjadi $\mathrm{X} 1$, Kinerja diubah menjadi $\mathrm{X} 2$, dan Kepatuhan diubah menjadi X3.

TABEL 3

\begin{tabular}{|c|c|c|c|c|c|}
\hline \multirow{2}{*}{ Alternatif } & \multicolumn{3}{|c|}{ Kriteria } & \multirow{2}{*}{ Jumlah } & \multirow{2}{*}{ Cluster } \\
\hline & C1 & $\mathrm{C2}$ & C3 & & \\
\hline A1 & 11 & 72 & 14 & 97 & 3 \\
\hline $\mathrm{A} 2$ & 11 & 73 & 15 & 98 & 5 \\
\hline A3 & 11 & 73 & 15 & 98 & 2 \\
\hline A4 & 11 & 72 & 14 & 97 & 3 \\
\hline A5 & 11 & 73 & 15 & 98 & 3 \\
\hline A6 & 10 & 72 & 14 & 97 & 3 \\
\hline A7 & 10 & 72 & 14 & 97 & 3 \\
\hline A8 & 10 & 71 & 14 & 95 & 4 \\
\hline A9 & 10 & 71 & 14 & 95 & 1 \\
\hline A10 & 11 & 72 & 14 & 97 & 2 \\
\hline A11 & 7 & 62 & 12 & 82 & 5 \\
\hline A12 & 6 & 61 & 12 & 79 & 4 \\
\hline A13 & 5 & 60 & 12 & 78 & 2 \\
\hline A14 & 6 & 56 & 11 & 73 & 4 \\
\hline A15 & 9 & 60 & 12 & 81 & 1 \\
\hline A16 & 9 & 61 & 12 & 82 & 1 \\
\hline A17 & 8 & 60 & 12 & 80 & 2 \\
\hline A18 & 9 & 61 & 12 & 82 & 4 \\
\hline A19 & 10 & 60 & 12 & 82 & 1 \\
\hline A20 & 9 & 60 & 12 & 82 & 1 \\
\hline A21 & 9 & 65 & 13 & 87 & 2 \\
\hline A22 & 9 & 64 & 13 & 86 & 1 \\
\hline A23 & 8 & 64 & 13 & 85 & 1 \\
\hline
\end{tabular}

HASIL INISIALISASI DATA SDP 


\begin{tabular}{|c|c|c|c|c|c|} 
A24 & 9 & 69 & 14 & 91 & 2 \\
\hline A25 & 9 & 69 & 14 & 91 & 5 \\
\hline A26 & 10 & 70 & 14 & 94 & 1 \\
\hline A27 & 10 & 69 & 14 & 92 & 1 \\
\hline
\end{tabular}

\section{Page 190 C. Proses Data}

Setelah data diolah, maka langkah selanjutnya adalah data diproses untuk membentuk pengelompokan data ke dalam daftar program SDP sesuai kriteria yang telah ditentukan. Data yang telah ditransformasi tersebut akan diproses dengan menggunakan sebuah algoritma pengelompokan (cluster) yaitu algoritma $K$-means. Berikut ini adalah sebuah flowchart dalam pengelompokan program SDP pada Program SDP di HCG Pada PT. Bank Syariah Mandiri Pematangsiantar.

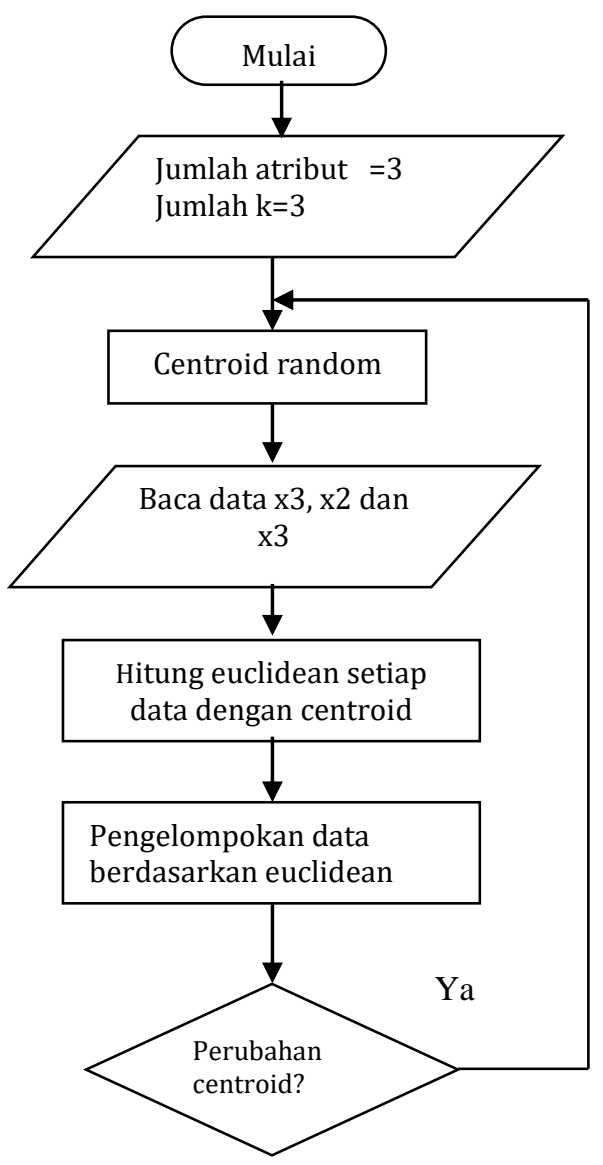

Gbr. 2 Flowchart Pengclusteran K-Means

Pada tahapan ini yaitu menentukan centroid $K$ means dari data Program SDP tahun 2017. Dalam menentukan target $K$-means tersebut bertujuan untuk mendapatkan target data atau jarak kelompok yaitu titik pusat (centroid) kelompok awal untuk menghitung algoritma K-means. Pada tabel 4 merupakan hasil perhitungan $K$-means untuk data sampel Program SDP baru periode tahun 2017 pada
HCG di PT.Bank Syariah Mandiri Pematangsiantar yang berdasarkan kriteria-kriteria yang telah ditentukan untuk setiap kelompok (cluster).

Dalam hal ini, pengelompokan yang terbentuk terjadi sebanyak 3 kelompok (cluster). Untuk representase perhitungan secara lengkap dapat dilihat pada tabel - tabel berikut:

TABEL 4

TARGET K-MENS DATA SAMPEL PROGRAM SDP UNTUK

\begin{tabular}{|c|c|c|c|}
\hline \multirow{2}{*}{ NIP } & \multicolumn{3}{|c|}{ KRITERIA } \\
\cline { 2 - 4 } & C1 & C2 & C3 \\
\hline 108675347 & 10 & 71 & 14 \\
\hline 098673907 & 9 & 60 & 12 \\
\hline 118679651 & 9 & 61 & 12 \\
\hline 118578195 & 10 & 60 & 12 \\
\hline 108277016 & 9 & 60 & 12 \\
\hline 118778861 & 9 & 64 & 13 \\
\hline 118679219 & 8 & 64 & 13 \\
\hline 108775315 & 10 & 70 & 14 \\
\hline 098574221 & 10 & 69 & 14 \\
\hline cluster 1 & $\mathbf{9}$ & $\mathbf{6 5}$ & $\mathbf{1 3}$ \\
\hline
\end{tabular}

Setelah pengelompokan untuk kelompok pertama(cluster-1) telah terkelompok. Maka dapat dilakukan untuk pengelompokan data kelompok kedua (cluster-2).

TABEL 5

TARGET $K$-MENS DATA SAMPEL PROGRAM SDP UNTUK $\mathrm{C} 2$

\begin{tabular}{|c|c|c|c|}
\hline \multirow{2}{*}{ NIP } & \multicolumn{3}{|c|}{ KRITERIA } \\
\cline { 2 - 4 } & C1 & C2 & C3 \\
\hline 108576825 & 11 & 73 & 15 \\
\hline 118579634 & 11 & 72 & 14 \\
\hline 078273284 & 5 & 60 & 12 \\
\hline 117879655 & 8 & 60 & 12 \\
\hline 108576854 & 9 & 65 & 13 \\
\hline 128810764 & 9 & 69 & 14 \\
\hline 128412364 & 11 & 72 & 14 \\
\hline 108576834 & 11 & 72 & 14 \\
\hline 118510236 & 11 & 73 & 15 \\
\hline 128911296 & 10 & 72 & 14 \\
\hline 1107775207 & 10 & 72 & 14 \\
\hline Cluster 2 & $\mathbf{1 0}$ & $\mathbf{6 9}$ & $\mathbf{1 4}$ \\
\hline
\end{tabular}

Data yang dikelompokan lainnya akan masuk pada kelompok 3 (cluster 3) yaitu terdapat tujuh record data pada kelompok 3 . 
TABEL 6

TARGET K-MENS DATA SAMPEL PROGRAM SDP UNTUK C3

Page $\mid 91$

\begin{tabular}{|c|c|c|c|}
\hline \multirow{2}{*}{ NIP } & \multicolumn{3}{|c|}{ KRITERIA } \\
\cline { 2 - 4 } & $\mathbf{C 1}$ & $\mathbf{C 2}$ & $\mathbf{C 3}$ \\
\hline 108675118 & 10 & 71 & 14 \\
\hline 108575319 & 6 & 61 & 12 \\
\hline 108275387 & 6 & 56 & 11 \\
\hline 128712213 & 9 & 61 & 12 \\
\hline 128211825 & 11 & 73 & 15 \\
\hline 118378913 & 7 & 62 & 12 \\
\hline 118579191 & 9 & 69 & 14 \\
\hline Cluster 3 & $\mathbf{8}$ & $\mathbf{6 5}$ & $\mathbf{1 3}$ \\
\hline
\end{tabular}

Setelah semua data telah terkelompok, maka untuk menentukan titik pusat pada cluster dapat diambil nilai rata - rata dari setiap. Adapun tahapan proses algoritma $K$-means adalah sebagai berikut:

1. Menentukan nilai $k$ dari jumlah cluster yang akan dibentuk. Pada tahap ini cluster yang terbentuk sebanyak 3 cluster.

2. Menentukan titik pusat (centroid) awal dari setiap cluster.

Dalam penelitian ini titik pusat awal ditentukan dengan menggunakan range dari program SDP.

TABEL 7

CENTROID AWAL CLUSTER

\begin{tabular}{|c|c|c|c|}
\hline Cluster & C1 & C2 & C3 \\
\hline X1 & 9 & 65 & 13 \\
\hline X2 & 10 & 69 & 14 \\
\hline X3 & 8 & 65 & 13 \\
\hline
\end{tabular}

Setelah titik pusat cluster ditentukan, maka tahap selanjutnya adalah menghitung jarak terdekat atau euclidean dengan menggunakan persamaan 3 , yaitu menghitung jarak dari data Program SDP pertama ke titik pusat cluster.

$$
\mathrm{D}(1,1)=\sqrt{(10-11)^{2}+(69-72)^{2}+(13-14)^{2}=16,8}
$$

Dari hasil perhitungan di atas didapatkan bahwa jarak terdekat bernilai 16,8 . Selanjutnya perhitungan jarak data pertama untuk cluster kedua.

$\mathrm{D}(1,2)=\sqrt{(9-11)^{2}+(64-73)^{2}+(13-15)^{2}=0,3}$
Dari hasil perhitungan tersebut didapatkan jarak terdekat bernilai 0,3 . Kemudian perhitungan jarak data pertama untuk cluster ketiga.

$$
\mathrm{D}(1,3)=\sqrt{(8-5)^{2}+(64-2)^{2}+(13-6)^{2}=2,0}
$$

Dari hasil perhitungan tersebut didapatkan jarak terdekat bernilai 2,0. Berdasarkan perhitungan euclidean untuk data pertama diperoleh jarak terdekat cluster adalah 16,8 yang terkelompok pada cluster kesatu (C1) dan untuk data kedua diperoleh jarak terdeka t cluster adalah 0,3 yang terkelompok pada cluster kedua (C2) dan untuk data ketiga diperoleh jarak terdekat cluster adalah 2,0.

TABEL 8

HASIL PROSES PERHIRUNGAN JARAK TERDEKAT (EUCLIDEAN)

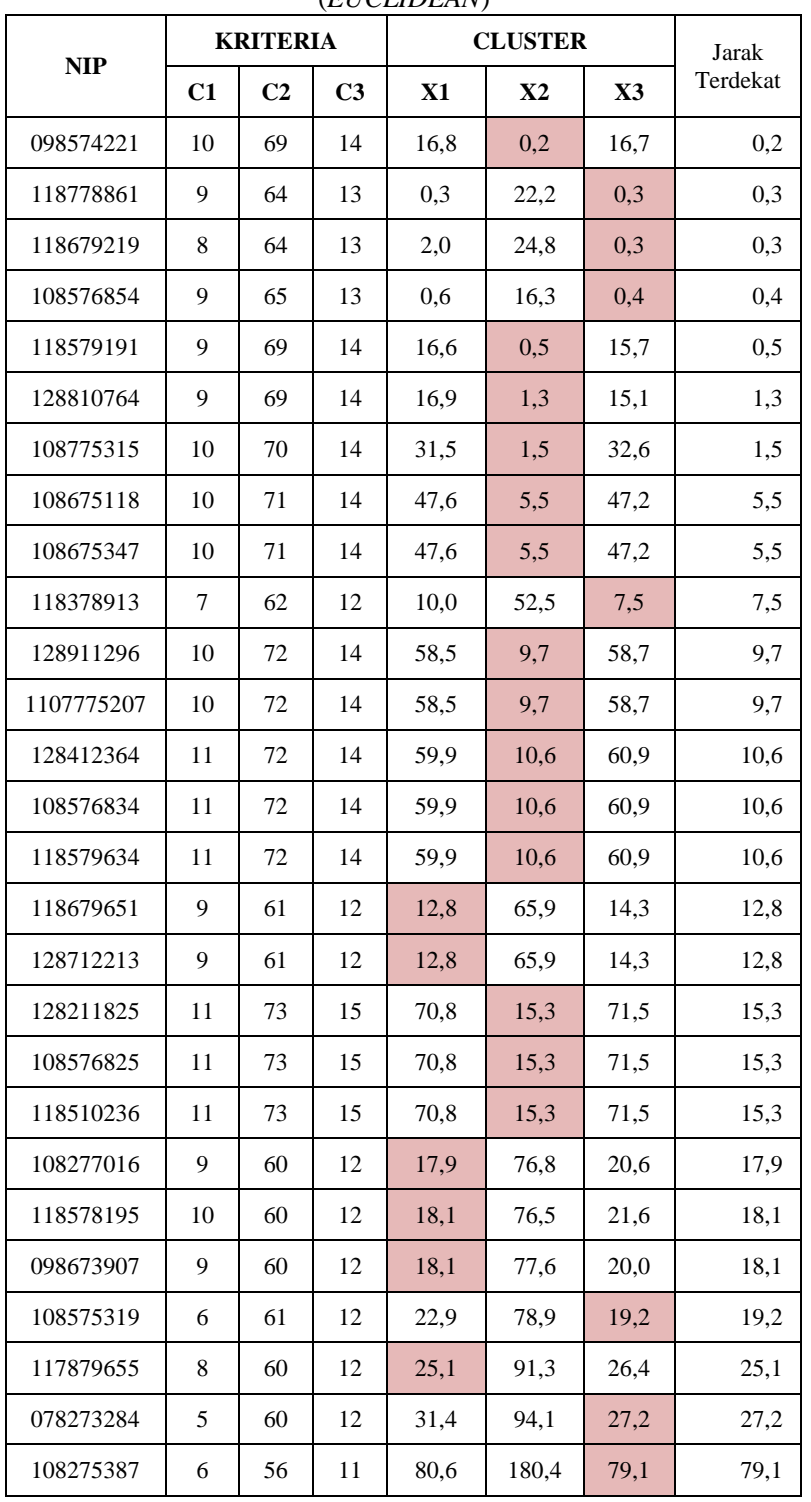

Setelah data dikelompokan pada iterasi pertama, maka langkah selanjutnya adalah membentuk titik pusat baru dengan menentukan nilai rata-rata dari 
setiap data yang sudah memebentuk cluster untuk melanjutkan perhitungan jarak terdekat iterasi kedua dan akan menunjukkan cluster yang terbentuk selanjutnya dapat membentuk cluster yang konvergen.

TABEL 9

CENTROID BARU PERTAMA

Page $\mid 92$

\begin{tabular}{|c|c|c|c|}
\hline Cluster & C1 & C2 & C3 \\
\hline 1 & 8,69 & 66,24 & 13,25 \\
\hline 2 & 9,50 & 69,62 & 13,92 \\
\hline 3 & 8,99 & 64,98 & 13,00 \\
\hline
\end{tabular}

Jika cluster belum konvergen, maka centroid akan dibangkitkan kembali dan menghitung kembali euclidean dari setiap data Program SDP. Langkah perhitungan jarak terdekat seperti langkah ketiga sebelumnya. Berikut perhirtungan jarak terdekat untuk data kedua.

$\mathrm{D}(2,1)=\sqrt{(3-8,69)^{2}+(3-66,24)^{2}+(3-13,25)^{2}=2,0518}$

Dari hasil perhitungan tersebut didapatkan jarak terdekat bernilai 2.0518. Untuk perhitungan euclidean dapat dilihat secara lengkap pada tabel di bawah ini.

TABEL 10

PERHITUNGAN EUCLIDEAN ITERASI-2

\begin{tabular}{|c|c|c|c|c|c|c|c|}
\hline \multirow{2}{*}{ NIP } & \multicolumn{3}{|c|}{ KRITERIA } & \multicolumn{3}{|c|}{ CLUSTER } & \multirow{2}{*}{$\begin{array}{c}\text { Jarak } \\
\text { Terd } \\
\text { ekat } \\
\text { ke } \\
\text { Clust } \\
\text { er }\end{array}$} \\
\hline & C1 & C2 & C3 & $\mathrm{X} 1$ & $\mathrm{X} 2$ & $\mathbf{X} 3$ & \\
\hline 108576854 & 9 & 65 & 13 & 1,2 & 21,5 & 0,2 & 0,2 \\
\hline 118778861 & 9 & 64 & 13 & 3,2 & 28,3 & 0,4 & 0,4 \\
\hline 108775315 & 10 & 70 & 14 & 16,9 & 0,9 & 27,3 & 0,9 \\
\hline 098574221 & 10 & 69 & 14 & 6,2 & 1,2 & 13,6 & 1,2 \\
\hline 118579191 & 9 & 69 & 14 & 5,7 & 1,4 & 13,3 & 1,4 \\
\hline 118679219 & 8 & 64 & 13 & 4,2 & 30,7 & 1,9 & 1,9 \\
\hline 128810764 & 9 & 69 & 14 & 5,5 & 2,0 & 13,4 & 2,0 \\
\hline 108675118 & 10 & 71 & 14 & 27,8 & 3,0 & 42,1 & 3,0 \\
\hline 108675347 & 10 & 71 & 14 & 27,8 & 3,0 & 42,1 & 3,0 \\
\hline 128911296 & 10 & 72 & 14 & 36,8 & 6,5 & 52,5 & 6,5 \\
\hline 1107775207 & 10 & 72 & 14 & 36,8 & 6,5 & 52,5 & 6,5 \\
\hline 128412364 & 11 & 72 & 14 & 38,5 & 7,5 & 54,0 & 7,5 \\
\hline 108576834 & 11 & 72 & 14 & 38,5 & 7,5 & 54,0 & 7,5 \\
\hline 118579634 & 11 & 72 & 14 & 38,5 & 7,5 & 54,0 & 7,5 \\
\hline 128211825 & 11 & 73 & 15 & 47,1 & 11,2 & 64,3 & 11,2 \\
\hline 108576825 & 11 & 73 & 15 & 47,1 & 11,2 & 64,3 & 11,2 \\
\hline 118510236 & 11 & 73 & 15 & 47,1 & 11,2 & 64,3 & 11,2 \\
\hline 118378913 & 7 & 62 & 12 & 18,6 & 60,9 & 11,5 & 11,5 \\
\hline 118679651 & 9 & 61 & 12 & 27,7 & 76,5 & 15,9 & 15,9 \\
\hline 128712213 & 9 & 61 & 12 & 27,7 & 76,5 & 15,9 & 15,9 \\
\hline
\end{tabular}

\begin{tabular}{|l|l|l|l|l|l|l|l|}
108277016 & 9 & 60 & 12 & 35,6 & 88,4 & 21,7 & 21,7 \\
\hline 098673907 & 9 & 60 & 12 & 35,4 & 89,1 & 21,9 & 21,9 \\
\hline 118578195 & 10 & 60 & 12 & 36,1 & 88,2 & 22,0 & 22,0 \\
\hline 108575319 & 6 & 61 & 12 & 35,5 & 88,8 & 25,4 & 25,4 \\
\hline 117879655 & 8 & 60 & 12 & 44,4 & 103,6 & 29,4 & 29,4 \\
\hline 078273284 & 5 & 60 & 12 & 46,0 & 104,8 & 34,4 & 34,4 \\
\hline 108275387 & 6 & 56 & 11 & 110,0 & 196,6 & 87,3 & 87,3 \\
\hline
\end{tabular}

Pada perhitungan jarak terdekat di atas centroid baru yang dibangkitkan ternyata belum konvergen, sehingga iterasi harus dilanjutkan. Dalam penelitian ini, iterasi clustering data Program SDP terjadi sebanyak 3 kali iterasi. Pada pengelompokan data di atas dan diperoleh titik cluster baru dengan nilai sebagai berikut:

TABEL 11

CENTROID BARU KEDUA

\begin{tabular}{|c|c|c|c|}
\hline Cluster & C1 & C2 & C3 \\
\hline 1 & 8,97 & 66,86 & 13,37 \\
\hline 2 & 10,41 & 71,70 & 14,34 \\
\hline 3 & 7,65 & 60,34 & 12,07 \\
\hline
\end{tabular}

Centroid baru kedua yang dibangkitkan ternyata sudah konvergen, sehingga perhitungan jarak terdekat clustering berhenti pada iterasi-3. Adapun perhitungan secara lengkapnya sebagai berikut:

TABEL 12

PERHITUNGAN EUCLIDEAN ITERASI-3

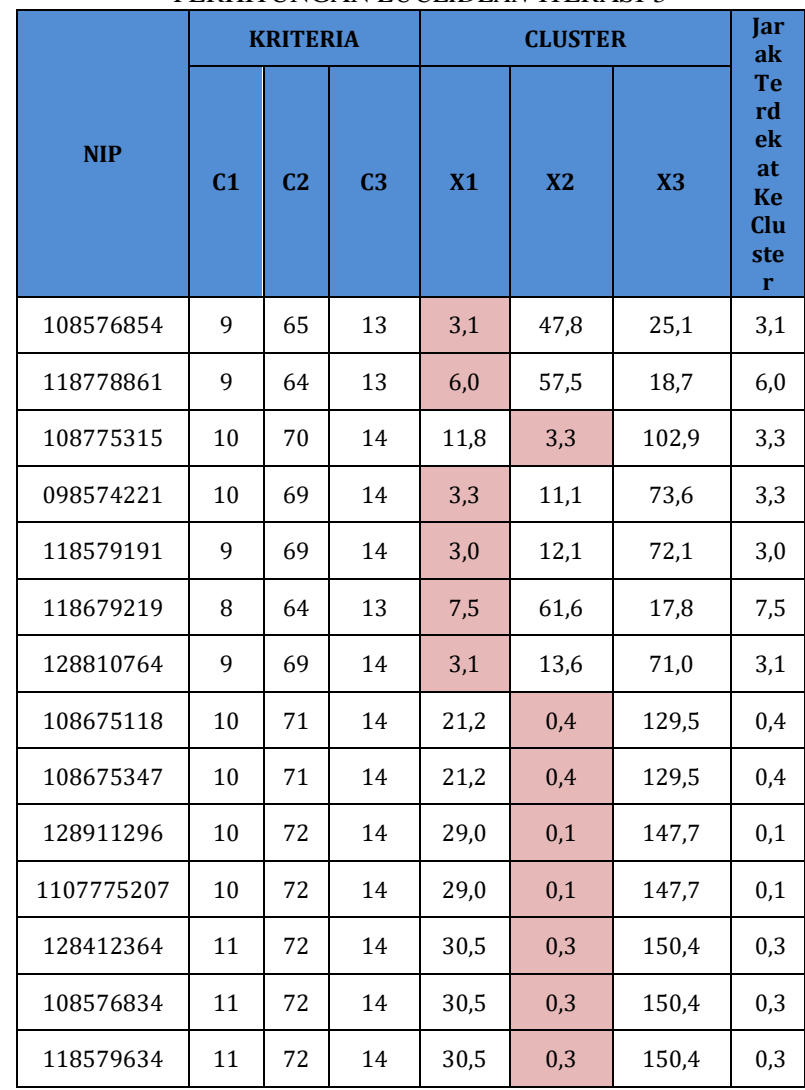




\begin{tabular}{|c|c|c|c|c|c|c|c|c|}
\hline 128211825 & 11 & 73 & 15 & 38,2 & 1,1 & 167,3 & 1,1 \\
\hline 108576825 & 11 & 73 & 15 & 38,2 & 1,1 & 167,3 & 1,1 \\
\hline 118510236 & 11 & 73 & 15 & 38,2 & 1,1 & 167,3 & 1,1 \\
\hline 118378913 & 7 & 62 & 12 & 25,0 & 102,2 & 5,3 & 5,3 \\
\cline { 2 - 9 } Page | 93 118679651 & 9 & 61 & 12 & 34,8 & 120,4 & 1,5 & 1,5 \\
\cline { 2 - 9 } & 128712213 & 9 & 61 & 12 & 34,8 & 120,4 & 1,5 & 1,5 \\
\hline 108277016 & 9 & 60 & 12 & 43,2 & 134,4 & 2,0 & 2,0 \\
\hline 098673907 & 9 & 60 & 12 & 43,4 & 135,9 & 0,9 & 0,9 \\
\hline 118578195 & 10 & 60 & 12 & 43,5 & 133,4 & 3,4 & 3,4 \\
\hline 108575319 & 6 & 61 & 12 & 44,2 & 137,6 & 3,7 & 3,7 \\
\hline 117879655 & 8 & 60 & 12 & 53,5 & 154,1 & 0,6 & 0,6 \\
\hline 078273284 & 5 & 60 & 12 & 55,8 & 157,4 & 4,9 & 4,9 \\
\hline 108275387 & 6 & 56 & 11 & 7 & 266,0 & 19,8 & 19, \\
\hline
\end{tabular}

Pada iterasi-3 tersebut, titik pusat dari setiap cluster sudah tidak berubah dan tidak ada lagi terdapat data yang berpindah dari satu cluster ke cluster yang lain. Maka dari itu, data yang telah terkelompok sesuai dengan kriteria akan melanjutkan proses ujian Assesmen Center pada bagian HCG PT. Bank Syariah Mandiri Pematang siantar menggunakan model algoritma $K$-Means.

\section{KESIMPULAN}

Dari hasil penelitian yang telah dilakukan, maka penulis dapat menarik beberapa kesimpulan, diantaranya sebagai berikut:

1. Pengujian yang dilakukan dalam penelitian ini, iterasi clustering pada data daftar Program SDP terjadi sebanyak 3 kali iterasi.

2. Berdasarkan hasil cluster dengan menerapkan beberapa kriteria dari daftar Program SDP menggunakan algoritma $K$-Means dapat diambil pengelompokan dengan rata- rata data program SDP yang dapat melakukan Asessment center lanjutan adalah yang lolos dan hasil klasifikasi program SDP yang Hampir lolos harus memperbaiki Administrasi seperti Kedisiplinan dari bulan juni sampai bulan oktober agar dapat mengikuti Asessment Center lanjutan, sedangkan hasil klasifikasi daftar data program SDP yang Tidak lolos harus memperbaiki data kedisiplinannya selama 1 Tahun.

\section{REFERENSI}

[1] I Parlina, H Mawengkang, S Efendi InfoTekJar (2017) "Analisis Kinerja Algoritma Clustering Fuzzy Tsukamoto Dengan Fuzzy C-Means" (Jurnal Nasional Informatika dan Teknologi Jaringan) 1 (2), 90-94

[2] Nur, F., Zarlis, M., \& Nasution, B. B. (2017). Penerapan Algoritma K-Means Pada Siswa Baru Sekolahmenengah

Kejuruan Untuk Clustering Jurusan. InfoTekJar (Jurnal Nasional Informatika dan Teknologi Jaringan), 1(2), 100105.

[3] N Butarbutar, AP Windarto, D Hartama, S Solikhun Jurasik (Jurnal Riset Sistem Informasi dan Teknik Informatika) 1 (1), 46-55

[4] AP Windarto International Journal of artificial intelligence research 1 (2), 26-33

[5] MG Sadewo, AP Windarto, D Hartama InfoTekJar (Jurnal Nasional Informatika dan Teknologi Jaringan) 2 (1), 60-67

[6] AP Windarto "Implementation of Data Mining on Rice Imports by Major Country of Origin Using Algorithm Using K-Means Clustering Method" International Journal of Artificial Intelligence Research 1 (2)

[7] N Butarbutar, AP Windarto, D Hartama, S Solikhun

"Komparasi Kinerja Algoritma Fuzzy C-Means Dan KMeans Dalam Pengelompokan Data Siswa Berdasarkan Prestasi Nilai Akademik Siswa" Jurasik (Jurnal Riset Sistem Informasi dan Teknik Informatika) 1 (1), 46-55

[8] MG Sadewo, AP Windarto, D Hartama "Penerapan Datamining Pada Populasi Daging Ayam Ras Pedaging Di Indonesia Berdasarkan Provinsi Menggunakan K-Means Clustering" InfoTekJar (Jurnal Nasional Informatika dan Teknologi Jaringan) 2 (1), 60-67

[9] RW Sembiring, JM Zain, A Embong "Clustering high dimensional data using subspace and projected clustering algorithms" arXiv preprint arXiv:1009.0384

[10] PA Zizwan, M Zarlis, EB Nababan "Performance Analysis Of Combined Methods Of Genetic Algorithm And K-Means Clustering In Determining The Value Of Centroid" Journal of Physics: Conference Series 930 (1), 012008 